\title{
Chitosan and Laponite: a meta-analysis on their applications
}

\author{
Quitosana e Laponita: uma meta-análise de suas aplicações \\ Chitosán y Laponita: un meta-análisis de sus aplicaciones
}

Received: 09/22/2021 | Reviewed: 09/29/2021 | Accept: 10/04/2021| Published: 10/09/2021

\author{
Kelly Santana Lima \\ ORCID: https://orcid.org/0000-0002-2193-8511 \\ Federal University of Sergipe, Brazil \\ E-mail: kelly_quimica@live.com \\ Renata Silva-Mann \\ ORCID: https://orcid.org/0000-0001-5993-3161 \\ Federal University of Sergipe, Brazil \\ E-mail: renatamann@gmail.com \\ Victor Hugo Vitorino Sarmento \\ ORCID: https://orcid.org/0000-0001-6882-002X \\ Federal University of Sergipe, Brazil \\ E-mail: vhsarmento@gmail.com
}

\begin{abstract}
Chitosan is a renewable natural alkaline polysaccharide, and laponite is a multifunctional nanocomposite. Their use exists in several areas, mainly due to their non-toxicity and because chitosan is from natural resources. One primary use in seed coating processes consists of applying an exogenous material to the seeds, which can facilitate handling and planting. Thus, this study aimed to investigate the most appropriate uses in patented and publications related to the use of Laponite and Chitosan to access these materials' state of the art to identify perspectives for new research. One hundred two publications were explored in the scientific databases Scopus (53) and Web of Science (WoS) (79). Of these, duplicates were removed, totaling 93 articles with publications started in 2006 . The number of publications on chitosan and laponite for the countries with the highest number of corresponding authors was from China (27), Iran (16), and the United States (15). Brazil also stands out and occupies the fourth position regarding the number of corresponding authors (7). There were prospected 109 patents, and most of them have been used in medical or veterinary hygiene, or hygienic devices and methods $(\mathrm{A} 61 \mathrm{~K})$, in cosmetics (A61Q). The compilation and analysis of scientific, technological, and information use carried out in this work has allowed for identifying the new research perspectives and validated the potential use of chitosan and laponite association as a seed coating.
\end{abstract}

Keywords: Bibliometrics; Coating; Prospecting; Articles; Patents.

\section{Resumo}

Quitosana é um polissacarídeo alcalino natural e renovável, e laponita é um nanocompósito multifuncional. Seu uso existe em diversas áreas, principalmente devido à sua não toxicidade e porque a quitosana é oriunda de recursos naturais. Um dos principais usos é em processos de revestimento de sementes que consiste em aplicar um material exógeno às sementes, que pode ser usado para facilitar o manuseio e o plantio. Assim, o objetivo deste estudo foi investigar os usos mais relevantes em patentes e publicações relacionadas ao uso de laponita e quitosana para acessar o estado da arte desses materiais, a fim de identificar perspectivas para novas pesquisas. Foram avaliadas a produção científica e intelectual anual. Foram pesquisadas cento e trinta e duas publicações nas bases científicas Scopus (53) e Web of Science (WoS) (79). Destes, foram retiradas duplicatas, totalizando 93 artigos com publicações iniciadas em 2006. O número de publicações sobre quitosana e laponita para os países com maior número de autores correspondentes foi da China (27), Irã (16) e Estados Unidos (15). O Brasil também se destaca e ocupa a quarta posição em termos de número de autores correspondentes (7). Foram prospectadas 109 patentes, e a maioria delas tem uso em higiene médica ou veterinária, ou dispositivos e métodos higiênicos (A61K) e cosméticos (A61Q). A compilação e análise do uso científico, tecnológico e de informação realizado neste trabalho permitiu identificar as novas perspectivas de pesquisa e validou o uso potencial da associação de quitosana e laponita como revestimento de sementes.

Palavras-chave: Bibliometria; Revestimento; Prospecção; Artigos; Patentes.

\section{Resumen}

Quitosano es polisacárido alcalino natural renovable, la laponita es un nanocompuesto multifuncional. Su uso existe en varios ámbitos, principalmente por su no toxicidad y porque el quitosano procede de recursos naturales. Uno de los principales usos es en procesos de recubrimiento de semillas, aplicación un material exógeno a las semillas, lo que puede facilitar su manipulación y plantación. Así, el objetivo de este estudio fue investigar los usos más relevantes en 
patentes y publicaciones relacionadas con el uso de la Laponita y Quitosano para acceder al estado del arte destos materiales, con el fin de identificar perspectivas para nuevas investigaciones. Se evaluó la producción científica e intelectual anual. Se buscaron ciento treinta y dos publicaciones en las bases de datos científicas Scopus (53) y Web of Science (WoS) (79). De éstas, se eliminaron los duplicados, totalizando 93 artículos con publicaciones iniciadas en 2006. El número de publicaciones sobre quitosano y laponita de los países con mayor número de autores correspondientes fue de China (27), Irán (16) y Estados Unidos (15). Brasil también destaca y ocupa la cuarta posición en cuanto al número de autores correspondientes (7). Se prospectaron 109 patentes, la mayoría de ellas tiene uso en la higiene médica o veterinaria, o métodos higiénicos (A61K), en los cosméticos (A61Q). La recopilación y el análisis del uso científico, tecnológico y de información realizado en este trabajo ha permitido identificar las nuevas perspectivas de investigación y validar el uso potencial de la asociación de quitosano y laponita como recubrimiento de semillas.

Palabras clave: Bibliometría; Recubrimiento; Prospección; Artículos; Patentes.

\section{Introduction}

Sustainability of products and services has become a compulsory requirement and an essential requirement for organizations, governments, markets, and society in general. Among the various ways of measuring sustainability developed, those based on life cycle thinking provide one of the frameworks for assessing the potential impacts of products and services. Despite sustainability, the life cycle assessment is a prominent available tool- the case of biocomposites built with naturebased materials harvested in several regions of the globe. So, the research of assessment methods applied to biocomposites reveals knowledge and information gaps to apply these methodologies (Rodriguez et al., 2020).

The use of laponite and chitosan eco-friendly and commercially is a new challenge to considerer the preconized bioeconomy aiming for sustainable materials. In this way, agriculture occupies a third of the earth's surface, moving billions of dollars and generating countless jobs (Rocha et al., 2019) requiring new eco-friendly materials. The growing demand for food, with several people worldwide, above 925 million, and prospects of reaching two billion by 2050 are new challenges. Another consideration is the combined features of the climate scenario and conventional practices, which makes it necessary to search for alternatives and develop new technologies that enable agriculture to meet these premises (Ehsanfar and Modarres-Sanavy, 2005; Ma, 2019; Rocha et al., 2019).

Given this, precision agriculture seeks to improve production, success, and profits, in addition to reducing the use of agrochemicals and reducing environmental impacts. The weakening of biodiversity and ecosystem productivity, an example of the replacement of native plants by exotic ones, is a problem that can contribute to the degradation and desertification of areas and a consequent drop in productivity (Madsen et al., 2016). To avoid a decrease in productivity, developing new technologies that re-establish the balance for plants and promote better agricultural productivity. However, the main barriers to ecosystem restoration can be mitigated by seed innovations. These innovations may involve using substances from natural raw materials and thus substituting synthetic products for natural ones with minimal environmental impact.

Seed coating moves billions of dollars in the agricultural sector and is a technique dominated by the private sector (Pedrini et al., 2017, 2020). This coating involves applying an exogenous material such as seeds, such as dyes and polymers that modify their shape and size. In addition, they facilitate the reduction of friction in agricultural machinery used in planting; but they can also contain biocontrol agents and microorganisms, which protect and improve the maintenance of seed quality and performance (Cruz et al., 2017; Rocha et al., 2019). Coatings on a large scale began in the 1960s (Sundhoro et al., 2017). There can be three types of coating: a) in the form of a film, which consists of applying a thin layer of material to the seed husk without modifying its shape and size, which improves its plantability; b) pelleting, which in turn modifies the size, weight, and shape of the seeds, making them more uniform, facilitating planting; and c) encrustation, which is intermediate to the other coatings regarding the modification of weight and thickness of material in the seeds (Pedrini et al., 2017; Ma, 2019; Rocha et al., 2019).

Growth-stimulating agents also contribute to plant productivity. Markers can be selected (nuclei) or not (fluorescent 
dyes) and allow tracking of batches as to the origin, the seed treatment, facilitate sowing, and make it difficult to counterfeit as pirates, thus guaranteeing the quality and origin of the seeds in the certification and inspection process. The availability of nutrients during plant growth is another factor that can be improved with agents related to coating. In this case, they can be essential micronutrients such as phosphorus $(\mathrm{P})$, potassium $(\mathrm{K})$, copper $(\mathrm{Cu})$, manganese $(\mathrm{Mn})$ and zinc $(\mathrm{Zn})$, other macro and micronutrients (Farooq et al., 2012; Bindraban et al., 2015). Triticum aestivum seeds coated with polymer enriched with Cu, $\mathrm{Mn}$, and $\mathrm{Zn}$ have greater absorption of nutrients such as nitrogen $(\mathrm{N}), \mathrm{P}$, and $\mathrm{Cu}$, in addition to developing more vigorous grains (Wiatrak, 2013).

Among the possibilities of raw material for use in coatings, chitosan is reported as antifungal agent and in Cynara escolymus, pea, and grape seeds (Chouhan \& Mandal, 2021; Ziani et al., 2010). However, some insulating protectors are careful because they can harm the environment and the ecosystem. Chitosan is a biopolymer, non-toxic, biodegradable, versatile, and very abundant. Obtained by the deacetylation of chitin from shrimp and crustacean shells, it is insoluble in water, limiting its applications. Chitosan has been used without seed coating, among other applications in agriculture (Chouhan \& Mandal, 2021). The use of chitosan in the form of a nano solution has expanded the possibility of its use (Divya et al., 2019; Li et al., 2019; Qu and Luo, 2020). The capacity of the hydrogel formed by chitosan to adsorb residues was necessary, which could act in the remediation of toxic compounds (Preethi et al., 2021).

In addition to attenuating abiotic stress on plants, chitosan positively affects seed germination and seedling growth rates at low temperatures ( $\mathrm{Li}$ et al., 2019; Qu and Luo, 2020). Chitosan nanocomposites can be chosen when this polymer is mixed with nanoclays, such as montmorillonite and laponite. Nanomaterials from this combination incorporate improved mechanical strength, antibacterial activity, and active transport (Qu and Luo, 2020). Chitosan can promote the induction of enzymes, such as glucanase, polysaccharides, such as chitins. In addition can induce plants to produce phenolic compounds, terpenoids, proteins, protease inhibitors, lignification, callus deposition, and combinations associated with oxidative make plants develop defense mechanisms. For this reason, chitosan is used to coat corn, tomato, rice, and wheat seeds, promote rates of germination, physiological quality, and vigor, in addition to inducing the natural defenses of plants. The use of agrochemicals combined with chitosan also has promising results (Cruz et al., 2017).

Laponite is a synthetic hectorite belonging to the class of hesmectites, which has the shape of nanometric disks (Afewerki et al., 2019; Maeda, 2019). Laponite is composed of layers of tetrahedral silica and octahedral sheets of magnesium oxide, with the chemical formula $\mathrm{Na}^{+0.7}\left[\left(\mathrm{Si}_{8} \mathrm{Mg}_{5.5}, \mathrm{Li}_{0.3}\right) \mathrm{O}_{20}(\mathrm{OH})_{4}\right]^{-0.7}$ (Dávila and d 'Ávila , 2017). Its discs have a negatively charged face and positively charged edges, which means that it can form a "card castle" structure around $2 \%$ by mass of clay in an aqueous medium. The suspension of laponite in water becomes a gel (Afewerki et al., 2019; Maeda, 2019). A laponite can swell, absorbing large amounts of water. In addition, it has high biocompatibility, anisotropic morphology and, a large contact surface. These characteristics make them suitable for developing nanocomposites and application in various areas of knowledge (Sheikhi et al., 2018; Afewerki et al., 2019).

With all the properties and benefits, the objective of this work was to search patents and articles that involve the use of chitosan and laponite and their applications in agriculture, especially in seed treatment. Considering the properties of chitosan and laponite and the needs of the agricultural industry for materials that can help increase productivity, protection, and plantability of seeds. In contrast, materials that do not pose risks to the environment and consumers are used. It was noted that the use of these materials in seed coating is promising.

\section{Methodology}

This study is descriptive and exploratory with a quantitative approach (Sakamoto \& Silveira, 2019). Use bibliometric analysis of articles contained in the Scopus (http://www.scopus.com) and Web of Science (http://www.webofknowledge.com) 
databases that were prospected in title or abstract of scientific articles. Metadata refers to scientific publications established in the two databases imported in BibTex format, removed duplicate files, combined as a single dataset, and with the help of $\mathrm{R}$ software version 4.0.2 (R Core Team, 2020) and RStudio version 1.1.463 (Team RStudio, 2016). To perform bibliometric analysis, statistics and construction of data matrices for bibliographic coupling, co-citation, scientific collaboration analysis; and keyword analysis, was used in the Bibliometrix package of the R software (Aria \& Cuccurullo, 2017) in an interface with the Biblioshny browser (http: /www.bibliometrix.org). The present research is a meta-analysis, a quantitative method that combines the information obtained from previous independent studies and, using statistical analysis, performs a critical analysis of these results (Hernandez et al., 2020). The keywords "chitosan" and "laponite" were defined, and searches were performed on the Scopus, Web of Science, and The Lens platforms.

\subsection{Review procedure}

The search for articles published in English in the last 15 years was carried out in April 2021, using Scopus (http://www.scopus.com) and Web of Science (http://www.webofknowledge.com) and conducted with combinations of the search terms "chitosan" AND "laponite." We retrieved the abstracts of 95 articles. Articles were selected by evaluating the title and abstract. The articles were reviewed to ensure that each study met the criteria for quantitative data on chitosan and laponite. The databases were imported in Bitex format. A meta-analysis was performed using software 4.0.0 (R Core Team, 2020) and RStudio 1.1.463 (RStudio Team, 2016). Bibliographic coupling, co-citation, collaborative analysis, and keywords were performed for bibliometric analysis and construction of data matrices. The "Bibliometrix" package of the R software was used for bibliometric analysis to create graphics (Aria and Cuccurullo, 2017). Complementary dataset 1.

\subsection{Patents prospection}

The prospection of patents was carried out in April 2021 through The Lens platform (https://www.lens.org) which performs searches in Espacenet databases - European Patent Office, USPTO - United States Patent and Trademark Office Database, WIPO - World Intellectual Property Organization and IP Australia covering over 95 different jurisdictions, and providing access to over 100 million patents. A search was performed with "chitosan" and "laponite" used with "AND," which these keywords in the title, abstract, and description text of the patents. Data on applicants, inventors, citations, international patent classifications, geographic and temporal distribution were analyzed. Data from the last 25 years were collected, data in which there was the first deposit.

\section{Results}

\subsection{Review procedure}

One hundred thirty-two publications were searched in the scientific databases Scopus (53) and Web of Science (WoS) (79). Of these, duplicates were removed, totaling 93 articles with publications started in 2006. The graphs representing the scientific productions are displayed in Figure 1. 
Figure 1. Annual production of the web of Science (A) and Scopus (B) databases for chitosan and laponite.

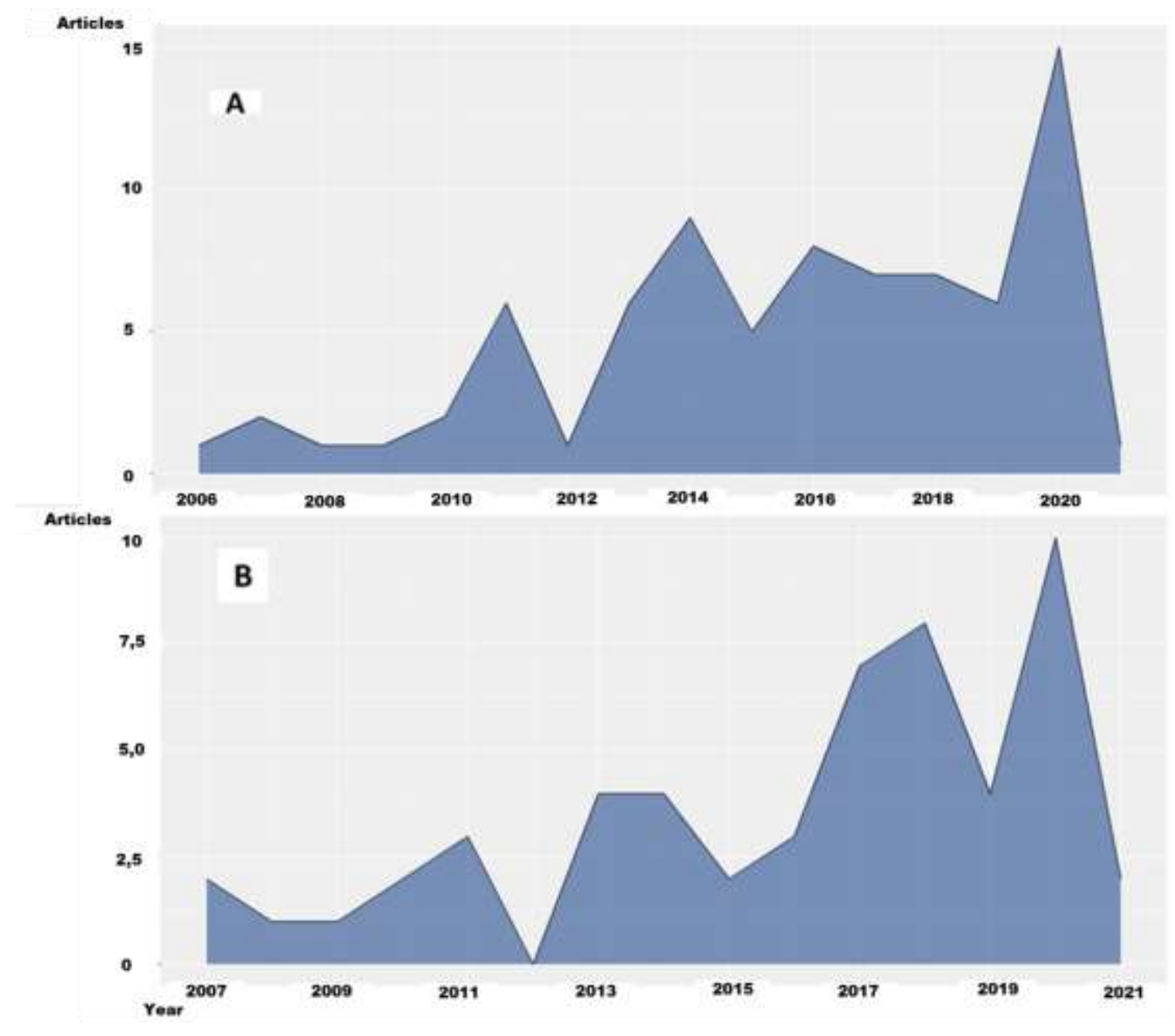

Source: Research data.

The number of publications on chitosan and advanced laponite from 2011 to 2020 presented the highest number of publications. The journal ACS Applied Materials \& Interfaces presented the highest number of published articles after identifying RSC Advances, Applied Clay Science, International Journal of Biological Macromolecules, and Macromolecular Bioscience. The ACS Applied Materials \& Interfaces, RSC Advances, and Applied Clay Science magazine, also the highest impact factors (Index H), with an ACS being the highest factor (5). 
Figure 2. Collaboration map by country of the web databases of Science (A) and Scopus (B) for chitosan and laponite.
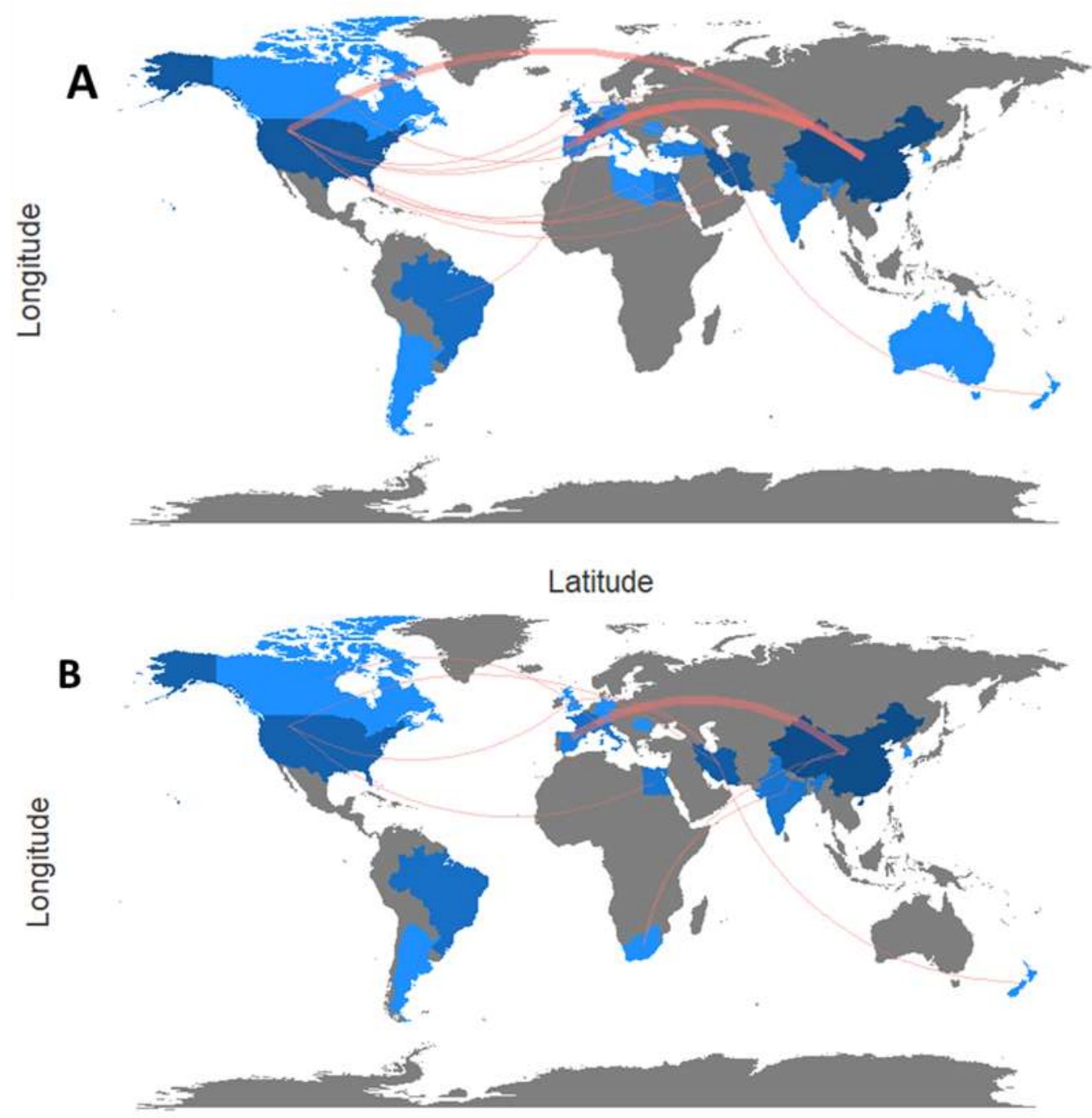

Latitude

Source: Research data.

As for the countries with the highest number of corresponding authors, China with the highest number of authors can be highlighted (27), Iran (16), and the United States (15). Brazil also stands out and occupies the fourth position regarding the number of corresponding authors, with seven authors, followed by India with four corresponding authors. Regarding the institutions with the highest number of publications, Maragheh University (Iran) stands out with the highest number, followed by Sharif University of Technology (Iran) and Yangzhou University (China). Among the countries that stand out in terms of collaboration with others, for Web of Science, we can mention: China (8), USA (7), and Iran (3), but Brazil, France, Libya, and Turkey also collaborated (Figure 2. ONE). For Scopus, the countries with the highest contributions were: China (5), Iran (4), USA (2). India (1) and Italy (1) (Figure 2. B). 
Figure 3. Scientific production of articles indexed in the web databases of Science (A) and Scopus (B) for chitosan and laponite, highlighting the most relevant authors per year.

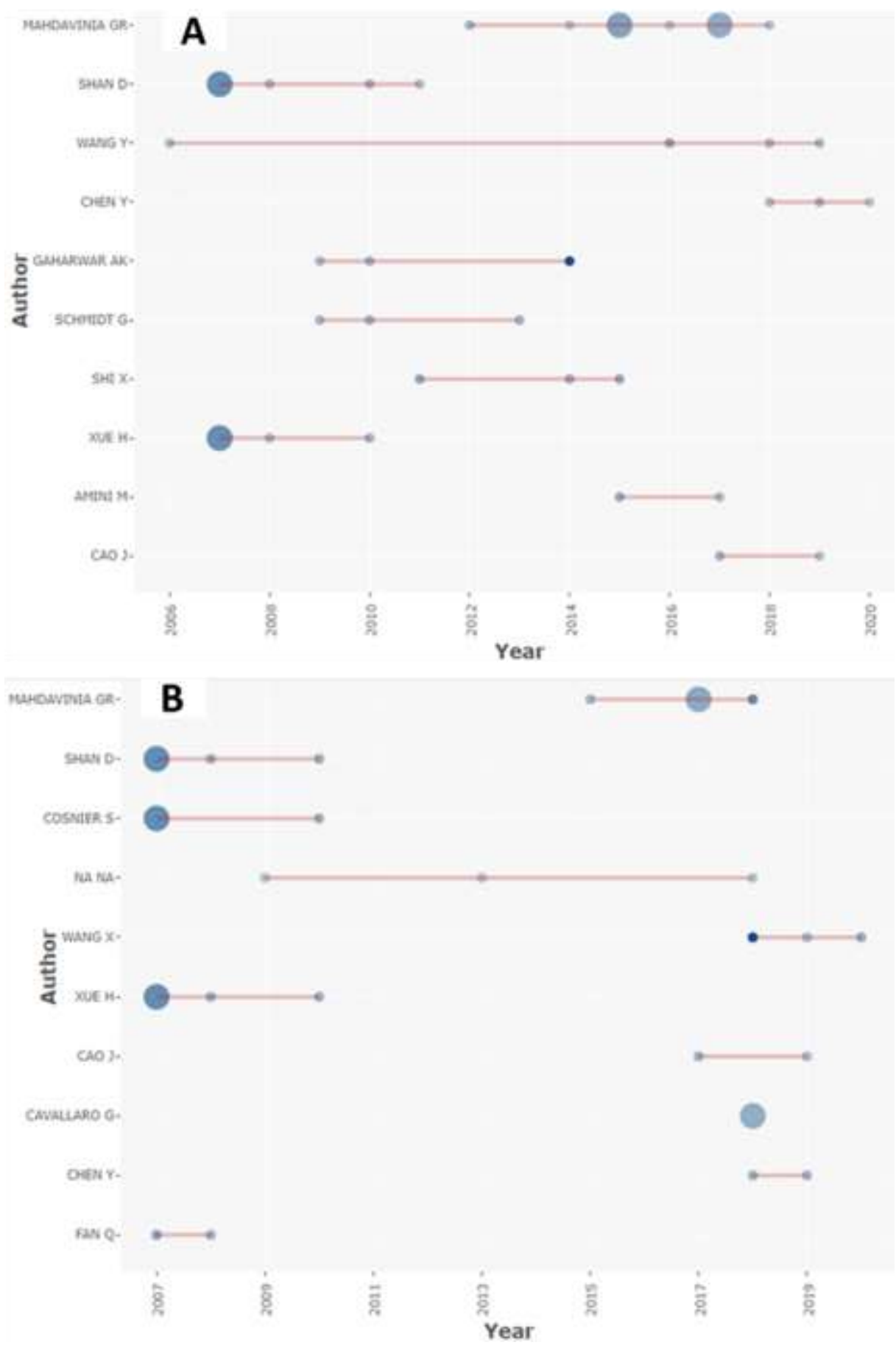

Source: Research data.

The most productive author was Mahdavinia G., followed by Shan D., and Wang Y. Graphs A and B of Figure 3 represent the authors' productions over the years for the two databases surveyed: Web of Science (WoS) and Scopus. The size of the spheres in Figure 3 represents the number of publications, while the color intensity represents the total number of citations per year by these authors. 
Figure 4. Cloud graphics with the most frequent keywords in the articles present in the Web of Science (A) and Scopus (B) databases.
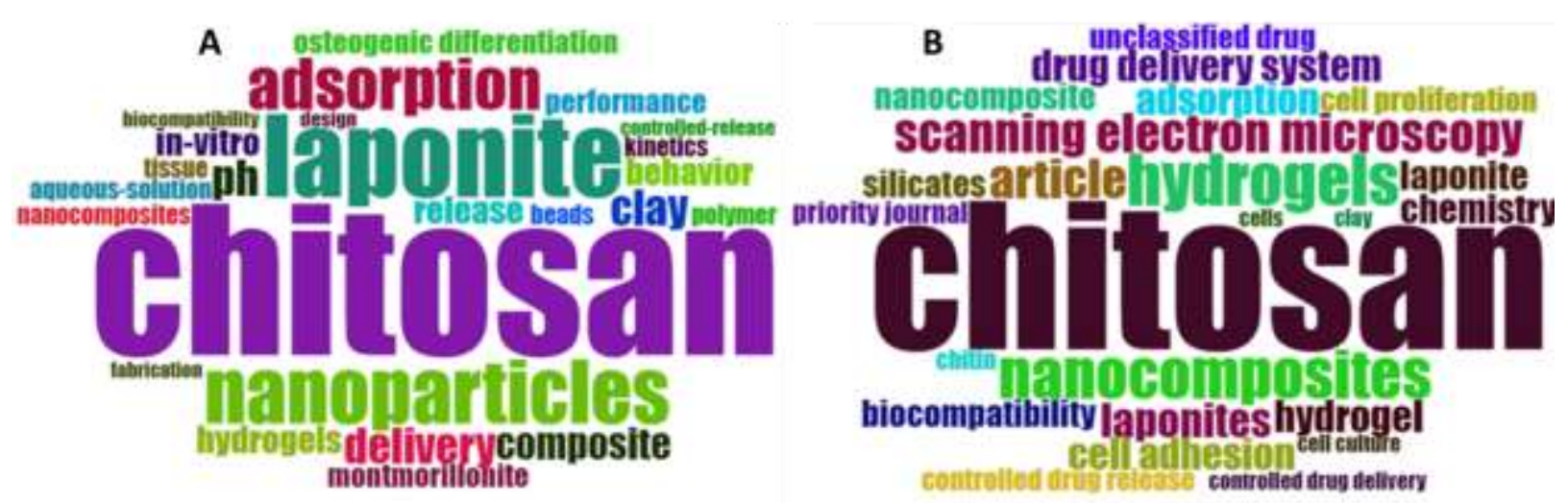

Source: Research data.

As for the number of citations, China is still in the first place, but the United States surpasses Iran in this regard. Brazil is surpassed by Portugal and India, being the sixth country with the highest number of citations for the number of citations. The most used keywords in the forums are "Laponite," "Chitosan", "Nanocomposite", "Hydrogels" and "Laponite RD"; the cloud graphics in Figure 4 indicate the words that appear most frequently.

Figure 5. Structural conceptual map of the most frequent terms in the keywords of the Web of Science database by the MCA method (A). Dendrogram with two groups with words found in the titles of articles in the Web of Science database (B).

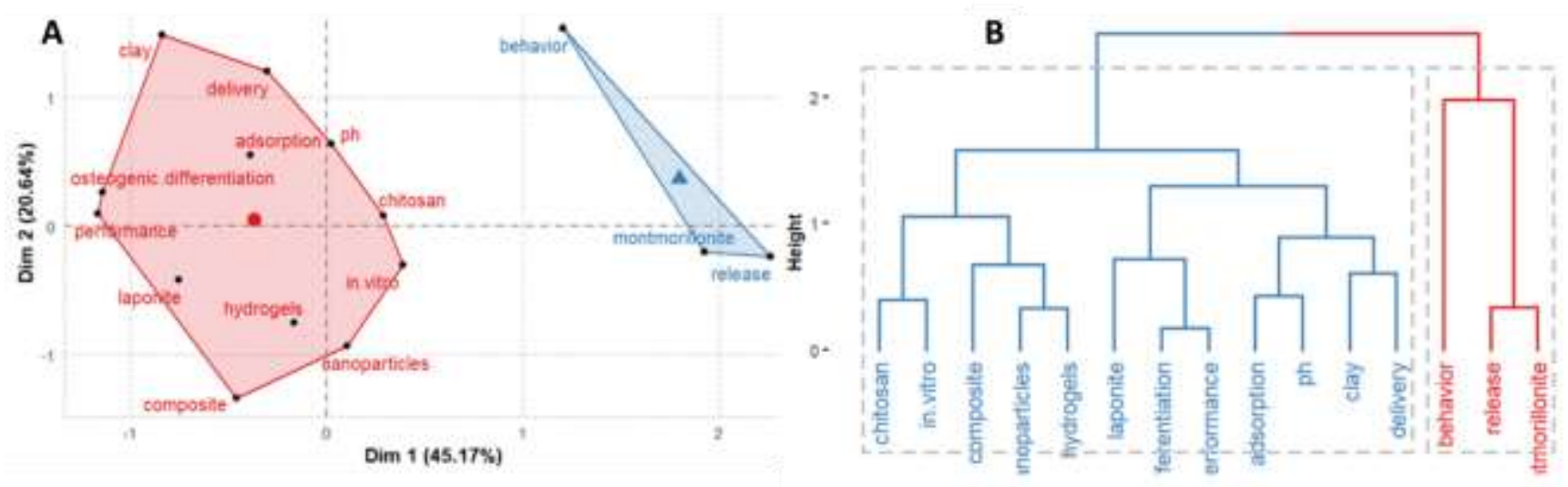

Source: Research data.

From the keywords of the articles obtained, the concept maps are still presented, with the most frequent words in the articles found in the Web of Science database. The multiple correspondence analysis (MCA) method and two co-occurrence networks were generated, represented in Figure 5. A by the red colors (chitosan, in.vitro, composite, nanoparticles, hydroles, laponite, osteogenic.differentiation, performance, adsorption, $\mathrm{pH}$, clay, delivery) and blue (behavior, release, montmorillonite). Through these data, it is possible to know the most studied themes. 
Figure 6. Structural conceptual map of the most frequent terms in the keywords of the Scopus database by the MCA method (A). Dendrogram with two groups with words found in the titles of articles in the base titles of articles in the Scopus base (B).
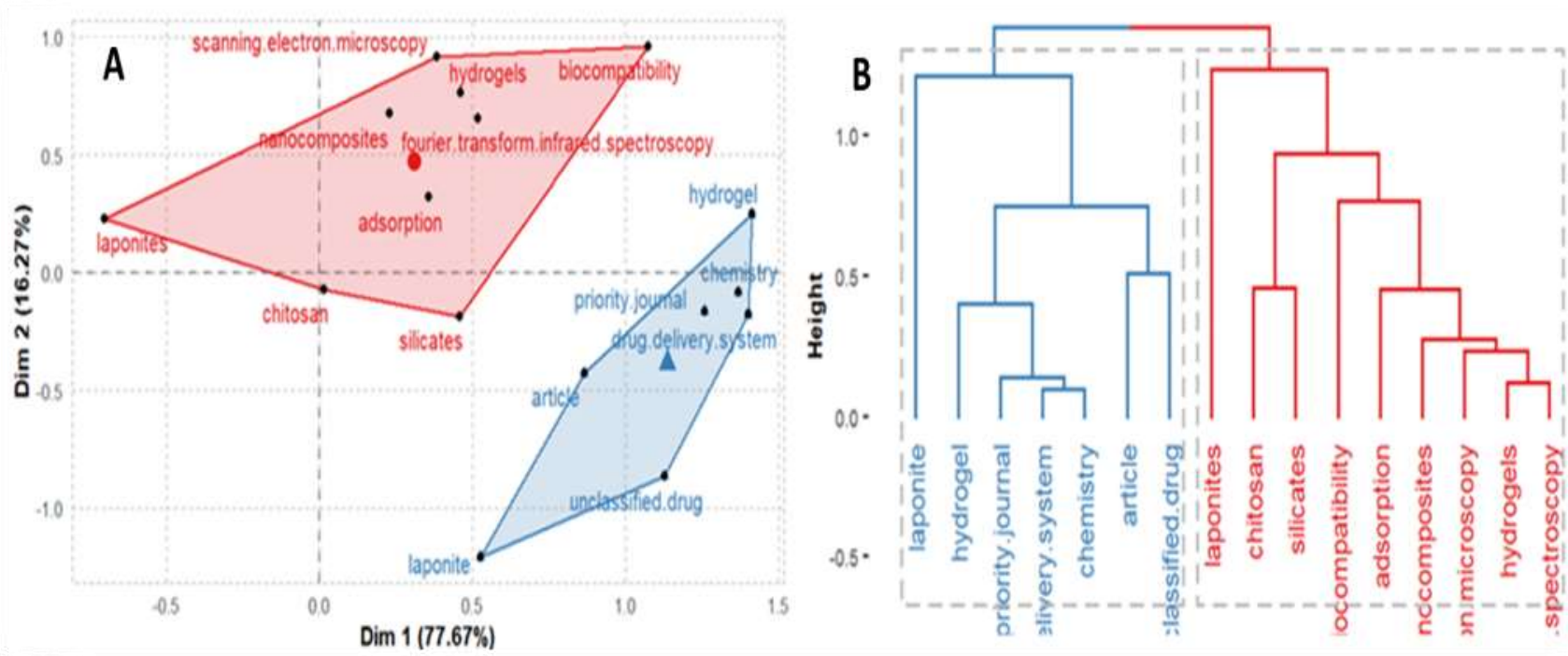

Source: Research data.

For the Scopus database we also used the keywords of the articles to obtain the co-occurrence networks and the structural conceptual maps, with the most frequent words, using the multiple correspondence analysis (MCA) method, the data can be

found in Figure 6, in red (chitosan, hydrogels, nanocomposites, scanning. electron.microscopy, laponites, adsorption, biocompatibility, fourier.transform.infrared.spectroscopy, silicates) and blue (article, drug.delivery.system, chemistry, laponite, hydrogel, unclassified.drug, priority.journal) again these graphs provide data about the most studied contents.

\subsection{Patents prospections}

Of the 109 patents prospected that relate chitosan and Laponite, on The Lens platform, 28 are granted patents, and 81 are patent applications. The number of patients published per year is shown in Figure 7. 
Figure 7. The number of documents containing the terms "chitosan and laponite" over the years.

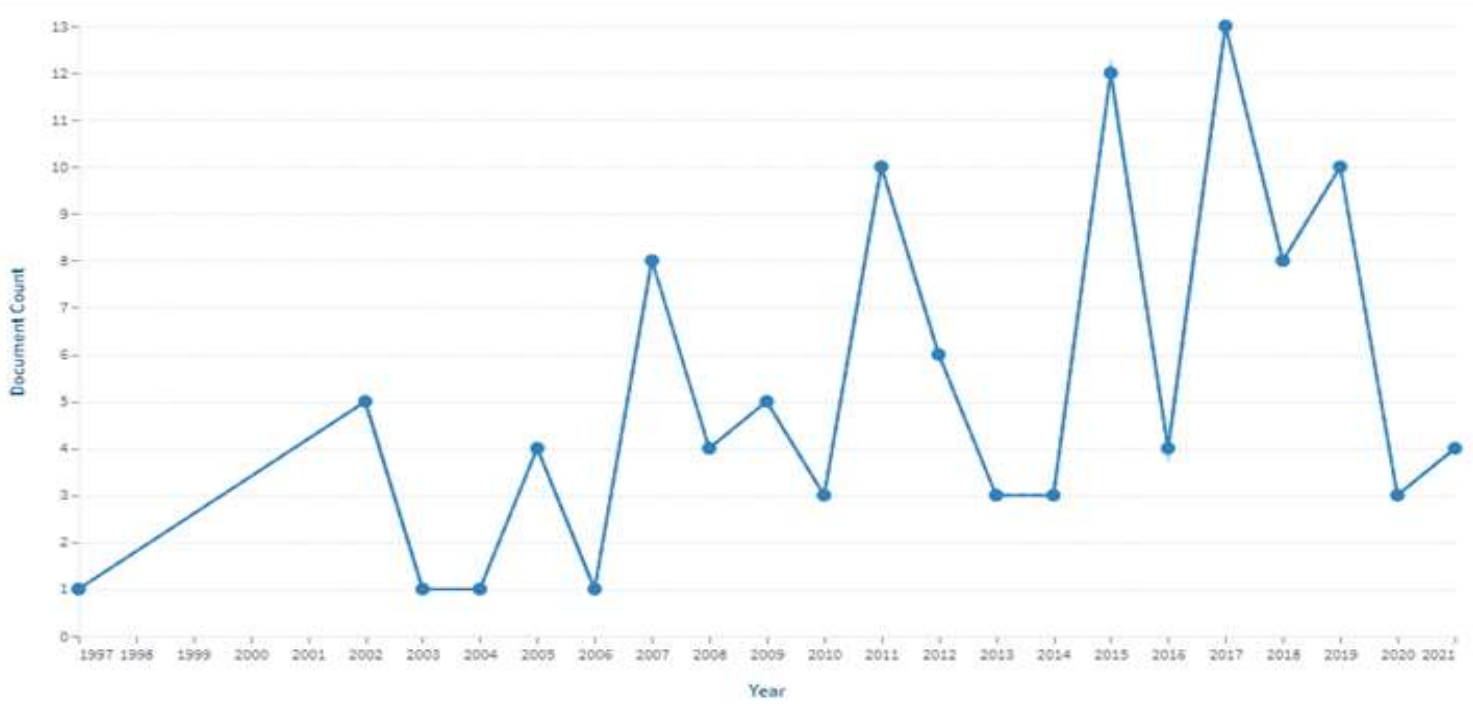

Source: Research data.

The first patent was filed on June 25, 1996. The following patent was filed. From this year, there was an increase in the number of filings between 2007 and 2008, the peak of patent filings (7). Data from patent filing data, citations, patent families, type, and the number of patents filed are represented in the scatter plot (Figure 8.A) and bar chart (Figure 8.B).

Figure 8. Scatter plot with the number of citations, patent family and type by filing data (A). Number of patents by type and year of filing (B).
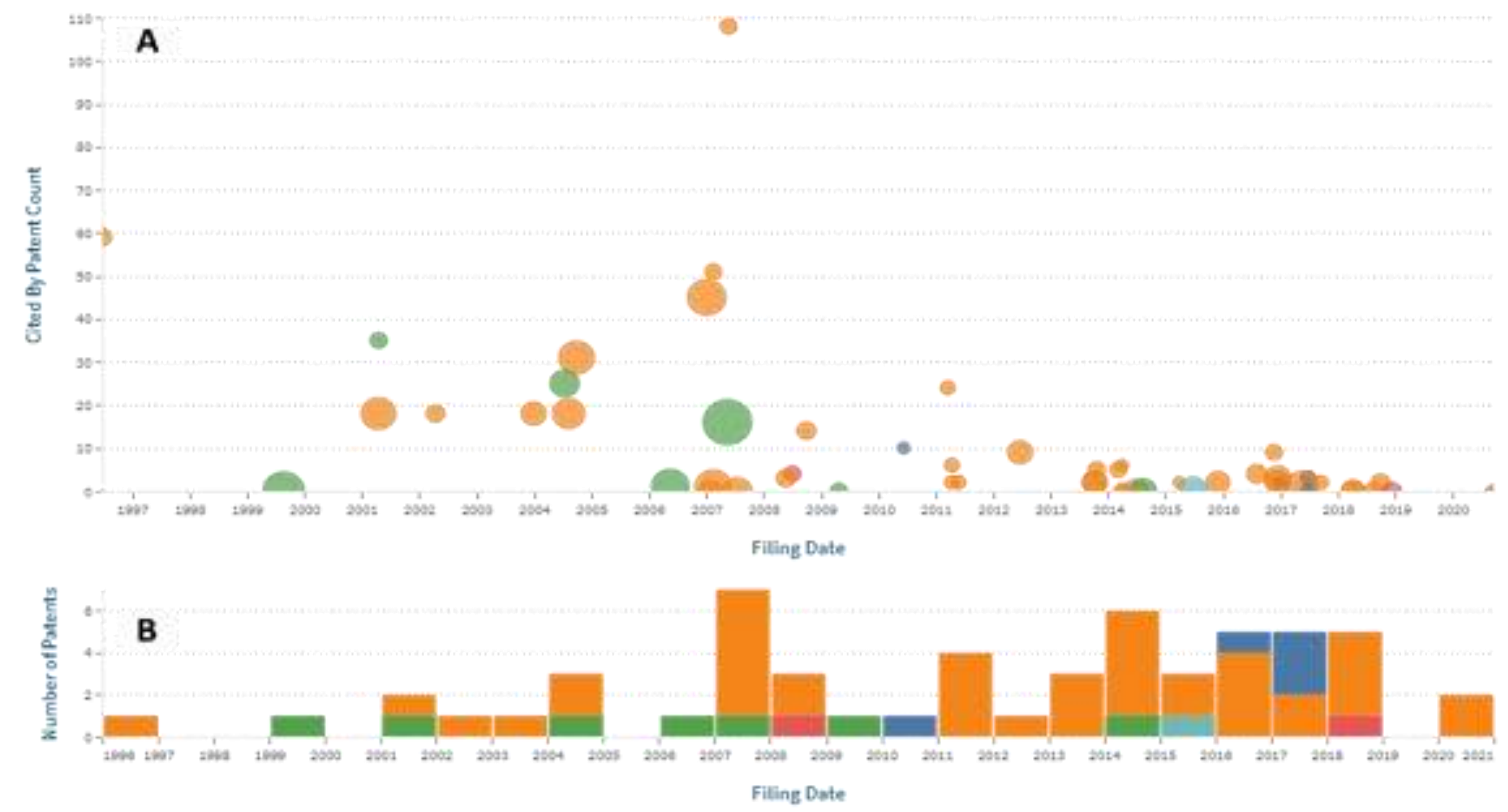

Kind Simple family Size

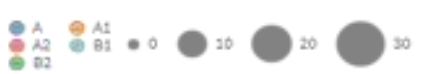

Source: Research data. 
The United States stands out with the highest number of patents (55) by jurisdiction, followed by WIPO (31), Australia (10), Europe (8), and China (5) patents.

Figure 9. Cloud graph referring to the number of documents deposited by the institution.

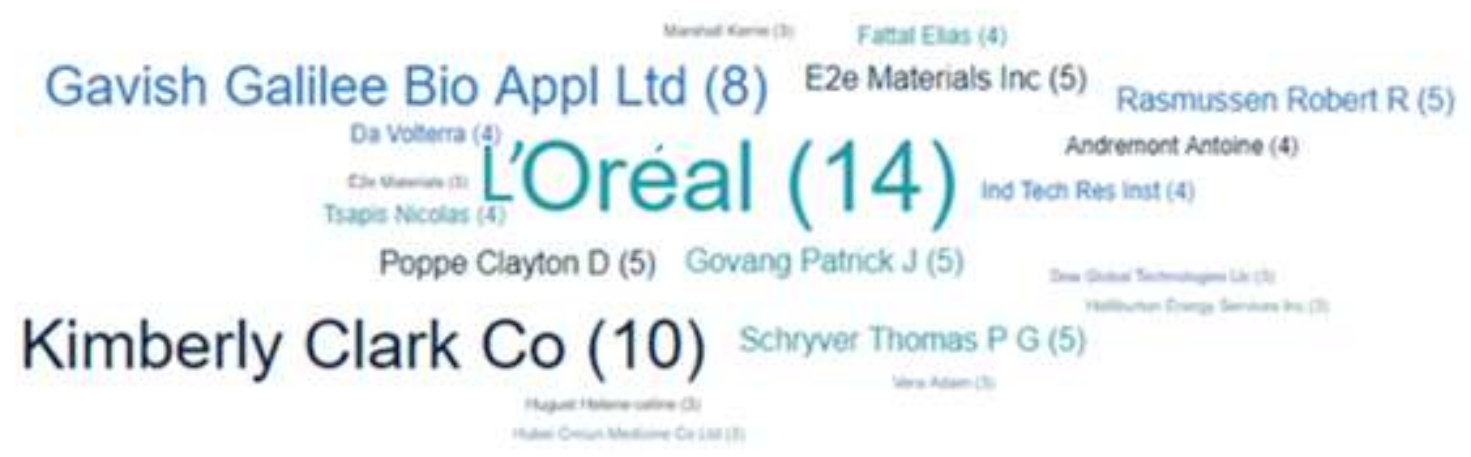

Source: Research data.

LOréal, a French multinational cosmetics company, has the most significant number of deposits, with 14 documents. Then there is Kimberly Clark Co (10), an American personal care company; Gavish Galilee Bio Applications Ltd, Israel's technology transfer company (8). Institutions with the highest number of deposits or orders are represented in the cloud graph in Figure 9. According to the International Patent Classification (IPC) classifications, the heat graph, the closer to the red coloration, the higher the frequency of patents (Figure 10).

Figure 10. Heat chart with the number of patents according to IPC classification.

\begin{tabular}{|c|c|c|c|c|}
\hline $\begin{array}{l}12 \\
\text { A6IKS } 02\end{array}$ & $\begin{array}{l}9 \\
\text { Aotks/s }\end{array}$ & $\begin{array}{l}5 \\
\text { A61kB/25 }\end{array}$ & $\begin{array}{l}8 \\
\text { A61KB/26 }\end{array}$ & $\begin{array}{l}5 \\
A 61 K 8 / 29\end{array}$ \\
\hline $\begin{array}{l}10 \\
\text { Naskins }\end{array}$ & $\begin{array}{l}15 \\
\text { A61K8/81 }\end{array}$ & $\begin{array}{l}6 \\
A_{6} 61 \mathrm{~K} / 00\end{array}$ & $\begin{array}{l}6 \\
\text { A61K9/20 }\end{array}$ & $\begin{array}{l}9 \\
\text { Aaikgiso }\end{array}$ \\
\hline $\begin{array}{l}7 \\
\text { A61Q19/10 }\end{array}$ & $\begin{array}{l}5 \\
\text { A61Q5/04 }\end{array}$ & $\begin{array}{l}6 \\
\text { B01D21/01 }\end{array}$ & $\begin{array}{l}5 \\
\mathrm{CO} 2 \mathrm{~F} 1 / 52\end{array}$ & $\begin{array}{l}9 \\
\text { consiges }\end{array}$ \\
\hline $\begin{array}{l}6 \\
\mathrm{CO}_{2} \mathrm{~F}_{103} / 20\end{array}$ & $\begin{array}{l}6 \\
C 02 F 103 / 22\end{array}$ & $\begin{array}{l}8 \\
\text { Co2f } 103 / 32\end{array}$ & $\begin{array}{l}6 \\
\cos K_{3} / 34\end{array}$ & $\begin{array}{l}6 \\
\text { G01N33/18 }\end{array}$ \\
\hline
\end{tabular}

Source: Research data.

Most of the prospected patents aim at the science of medical or veterinary hygiene and deal with preparing medical, dental, or hygienic devices and methods (A61K), explicitly using cosmetics or similar sanitary preparations (A61Q). Patents related to physical or chemical processes and apparatus, in general, were also found (B01D); water, wastewater, sewage or sludge treatment $(\mathrm{C} 02 \mathrm{~F})$; macromolecular compounds result from their preparation or working compositions based on them, use of inorganic or non-macromolecular organic substances as composition ingredients $(\mathrm{C} 08 \mathrm{~K})$ and for test tests, investigation or analysis of materials by determining their calls or physics $(\mathrm{G} 01 \mathrm{~N})$. The inventors with the highest number of documents are 
Rytwo (10), Govang Patrick J. (8), Rasmussen (8), Schryver Tomas P. (8), Utschig Julie M. (8), Poppe Clayton D. (8).

\section{Discussion}

In research, obtaining ideas is not enough to have a scientific work and receive a technological innovation without first knowing the art. What and how innovations are disseminated in the form of patents or scientific articles. The prospecting of this knowledge that updates on the correct state of the art will be made. Thus, focusing on obtaining innovations associated with seeds without toxicity levels using chitosan and laponite, this prospection study was carried out. Despite the growing interest in using these materials, as can be seen by the increase in the number of articles and patents filed each year, articles with chitosan and a laponite associated with seed coating on the same base were not found. However, these materials can be used in the coating of foods such as fruits (Wu et al., 2018), manufacture of biosensors (Shan et al., 2010), as biosensors for detection of phenols (Fan et al., 2007) and L-Lactate, which is an important food freshness and flavor standard (Zanini et al., 2011), in the adsorption of metals and dyes (Xu et al., 2019) and proteins (Mahdavinia et al., 2018).Most of these materials were combined for use in the medical field, an example of bioadhesive feeding and controlled drug administration (Gharaie et al., 2018; Chen et al., 2019; Raut et al., 2019; Nikfarjam and Kokabi, 2020; Rebitski et al., 2020), in the treatment of bleeding (Gaharwar et al., 2014) and wound treatment (Kiaee et al., 2018), improve cell adhesion and biomineralization (Gaharwar et al., 2010; Cebe et al., 2020), osteoinducers in bone tissue engineering (Zhang et al., 2020; Arab-Ahmadi et al., 2021). See the antifungal and antibacterial activities of chitosan and laponite these materials have been reported to regenerate skin and are promising determinants as curatives (Gonzaga et al., 2020).

Chitosan and laponite were also found in electrochemical applications, such as producing films for hydrogen peroxide catalysis (Shan et al., 2007). Hybrid chitosan and laponite coating were also applied to reduce fires in flexible polyurethane foams, widely used in mattresses and upholstery (Nabipour et al., 2020). Laponite not associated with chitosan was used for encapsulation and controlled release of drugs (Li et al., 2011; Gonçalves et al., 2014) and targeted drug release (Chen et al., 2015). Laponite was also used in adsorption pollutants in water and dyes (Mahdavinia et al., 2012). Chitosan is applied in the production of coatings, in edible coatings generally intended for coating fruits or grains. Furthermore, many applications are in the use of antibacterial and antifungal materials (Qu and Luo, 2020). Chitosan has also been used to produce composites for controlled insulin delivery (Feki et al., 2020).

Most of the articles found for isolated laponite and associated with chitosan also had application in other areas such as medicine and pharmacology. A patent search was also carried out requiring laponite for seed treatment. There is also a wide application of materials in the medical and cosmetic area in this search, with the company L'Oréal as one of the largest depositors. However, works were found that focused on the adsorption of materials and cleaning of wastewater and/or sewage. Thus, in the prospection based on the research, no articles were found that focus on the application of chitosan and laponite in material for seed coating, despite their characteristics such as antifungal, antibacterial, nontoxic properties, in addition to their use in food storage, or no drug transport demonstrating that these materials may have promising use in seed coating. Using these materials in isolation in the treatment and/or maintenance of the physical and physiological quality of seeds is promising. Therefore, studies that can associate these two materials with producing a new seed treatment, such as a coating that can associate properties for protection, hydration, and transporting actives to seeds, are transferred.

\section{Conclusion}

Considering the economic importance and the perspectives for population growth, the technological development of the agricultural environment is essential to obtain greater productivity, quality, and safety of the food purchased in an 
economically viable and environmentally sound way. In this aspect, chitosan and laponite, alone, can prove to be prosperous. However, there are no reports of works that combine the properties of these materials for this property. Thus, the development of new chitosan/laponite materials for seed treatment is promising, such as developing a clay-polymer coating with the ability to swell and release actives that can provide moisture and nutrients necessary for plant growth.

\section{Acknowledgments}

We thank the National Council for Scientific and Technological Development - Brazil (CNPq) and the Coordination for the Improvement of Higher Education Personnel - Brazil (CAPES).

\section{References}

Afewerki, S., Magalhães, L. S. S. M., Silva, A. D. R., Stocco, T. D., Silva Filho, E. C., Marciano, F. R., et al. (2019). Bioprinting a Synthetic Smectic Clay for Orthopedic Applications. Adv. Healthc. Mater. 8, 1-14.

Arab-Ahmadi, S., Irani, S., Bakhshi, H., Atyabi, F., and Ghalandari, B. (2021). Immobilization of carboxymethyl chitosan/laponite on polycaprolactone nanofibers as osteoinductive bone scaffolds. Polym. Adv. Technol. 32, 755-765.

Aria, M., and Cuccurullo, C. (2017). Bibliometrix: An R-tool for Comprehensive Science Mapping Analysis. J. Informetr. 11, 959-975.

Bindraban, P. S., Dimkpa, C., Nagarajan, L., Roy, A., and Rabbinge, R. (2015). Revisiting fertilisers and fertilisation strategies for improved nutrient uptake by plants. Biol. Fertil. Soils 51, 897-911.

Cebe, T., Ahuja, N., Monte, F., Awad, K., Vyavhare, K., Aswath, P., et al. (2020). Novel 3D-printed methacrylated chitosan-laponite nanosilicate composite scaffolds enhance cell growth and biomineral formation in MC3T3 pre-osteoblasts. J. Mater. Res. 35, 58-75.

Chen, G., Li, D., Li, J., Cao, X., Wang, J., Shi, X., et al. (2015). Targeted doxorubicin delivery to hepatocarcinoma cells by lactobionic acid-modified laponite nanodisks. New J. Chem. 39, 2847-2855.

Chen, Y., Kang, S., Yu, J., Wang, Y., Zhu, J., and Hu, Z. (2019). Tough robust dual responsive nanocomposite hydrogel as controlled drug delivery carrier of asprin. J. Mech. Behav. Biomed. Mater. 92, 179-187.

Dávila, J. L., and d’Ávila, M. A. (2017). Laponite as a rheology modifier of alginate solutions: Physical gelation and aging evolution. Carbohydr. Polym. 157, $1-8$.

Divya, K., Vijayan, S., Nair, S. J., and Jisha, M. S. (2019). Optimization of chitosan nanoparticle synthesis and its potential application as germination elicitor of Oryza sativa L. Int. J. Biol. Macromol. 124, 1053-1059.

Ehsanfar, S., and Modarres-Sanavy, S. A. (2005). Crop protection by seed coating. Commun. Agric. Appl. Biol. Sci. 70, $225-229$.

Fan, Q., Shan, D., Xue, H., He, Y., and Cosnier, S. (2007). Amperometric phenol biosensor based on laponite clay-chitosan nanocomposite matrix. Biosens. Bioelectron. 22, 816-821.

Farooq, M., Wahid, A., and Siddique, K. H. M. (2012). Micronutrient application through seed treatments -a review. J. Soil Sci. Plant Nutr. 12 , $125-142$.

Feki, A., Hamdi, M., Jaballi, I., Zghal, S., Nasri, M., and Ben Amara, I. (2020). Conception and characterization of a multi-sensitive composite chitosan-red marine alga-polysaccharide hydrogels for insulin controlled-release. Carbohydr. Polym. 236, 116046.

Gaharwar, A. K., Avery, R. K., Assmann, A., Paul, A., Mckinley, G. H., Khademhosseini, A., et al. (2014). Shear-Thinning Nanocomposite Hemorrhage. ACS Nano 8, 9833-9842.

Gaharwar, A. K., Schexnailder, P. J., Jin, Q., Wu, C. J., and Schmidt, G. (2010). Addition of chitosan to silicate cross-linked PEO for tuning osteoblast cell adhesion and mineralization. ACS Appl. Mater. Interfaces 2, 3119-3127.

Gharaie, S. S., Dabiri, S. M. H., and Akbari, M. (2018). Smart shear-thinning hydrogels as injectable drug delivery systems. Polymers (Basel). 10.

Gonçalves, M., Figueira, P., Maciel, D., Rodrigues, J., Shi, X., Tomás, H., et al. (2014). Antitumor efficacy of doxorubicin-loaded laponite/alginate hybrid hydrogels. Macromol. Biosci. 14, 110-120.

Gonzaga, V. de A. M., Poli, A. L., Gabriel, J. S., Tezuka, D. Y., Valdes, T. A., Leitão, A., et al. (2020). Chitosan-laponite nanocomposite scaffolds for wound dressing application. J. Biomed. Mater. Res. - Part B Appl. Biomater. 108, 1388-1397.

Kiaee, G., Mostafalu, P., Samandari, M., and Sonkusale, S. (2018). A pH-Mediated Electronic Wound Dressing for Controlled Drug Delivery. Adv. Healthc. Mater. 7, 1-8.

Li, R., He, J., Xie, H., Wang, W., Bose, S. K., Sun, Y., et al. (2019). Effects of chitosan nanoparticles on seed germination and seedling growth of wheat (Triticum aestivum L.). Int. J. Biol. Macromol. 126, 91-100. 
Li, Y., MacIel, D., Tomás, H., Rodrigues, J., Ma, H., and Shi, X. (2011). PH sensitive Laponite/alginate hybrid hydrogels: Swelling behaviour and release mechanism. Soft Matter 7, 6231-6238.

Ma, Y. (2019). Seed coating with beneficial microorganisms for precision agriculture. Biotechnol. Adv. 37, 107423.

Madsen, M. D., Davies, K. W., Boyd, C. S., Kerby, J. D., and Svejcar, T. J. (2016). Emerging seed enhancement technologies for overcoming barriers to restoration. Restor. Ecol. 24, S77-S84.

Maeda, T. (2019). Structures and applications of thermoresponsive hydrogels and nanocomposite-hydrogels based on copolymers with poly (Ethylene glycol) and poly (lactide-co-glycolide) blocks. Bioengineering 6,1-18.

Mahdavinia, G. R., Massoudi, A., Baghban, A., and Massoumi, B. (2012). Novel carrageenan-based hydrogel nanocomposites containing laponite RD and their application to remove cationic dye. Iran. Polym. J. (English Ed. 21, 609-619.

Mahdavinia, G. R., Soleymani, M., Etemadi, H., Sabzi, M., and Atlasi, Z. (2018). Model protein BSA adsorption onto novel magnetic chitosan/PVA/laponite RD hydrogel nanocomposite beads. Int. J. Biol. Macromol. 107, 719-729.

Nabipour, H., Wang, X., Song, L., and Hu, Y. (2020). Laponite-based inorganic-organic hybrid coating to reduce fire risk of flexible polyurethane foams. Appl. Clay Sci. 189, 105525.

Nikfarjam, M., and Kokabi, M. (2020). Chitosan/laponite nanocomposite nanogels as a potential drug delivery system. Polym. Bull.

Pedrini, S., Merritt, D. J., Stevens, J., and Dixon, K. (2017). Seed coating: science or marketing spin? Trends Plant Sci. 22, $106-116$.

Qu, B., and Luo, Y. (2020). Chitosan-based hydrogel beads: Preparations, modifications and applications in food and agriculture sectors - A review. Int. J. Biol. Macromol. 152, 437-448.

R Core Team (2020). R: A Language and environment for statistical computing. Vienna: R Foundation on Statistical Computing.

Raut, S. Y., Gahane, A., Joshi, M. B., Kalthur, G., and Mutalik, S. (2019). Nanocomposite clay-polymer microbeads for oral controlled drug delivery: Development and, in vitro and in vivo evaluations. J. Drug Deliv. Sci. Technol. 51, 234-243.

Rebitski, E. P., Darder, M., Carraro, R., and Ruiz-Hitzky, E. (2020). Chitosan and pectin core-shell beads encapsulating metformin-clay intercalation compounds for controlled delivery. New J. Chem. 44, 10102-10110.

Rocha, I., Ma, Y., Souza-Alonso, P., Vosátka, M., Freitas, H., and Oliveira, R. S. (2019). Seed Coating: A Tool for Delivering Beneficial Microbes to Agricultural Crops. Front. Plant Sci. 10.

Rodriguez, L. J., Peças, P., Carvalho, H., \& Orrego, C. E. (2020). A literature review on life cycle tools fostering holistic sustainability assessment: An application in biocomposite materials. Journal of environmental management, 262, 110308.

RStudio Team (2016). RStudio: Integrated Development for R. MA RStudio.

Ruiz de la Cruz, G., Aguirre Mancilla., C., Godínez-Garrido, N., Osornio-Flores, N., and Torres Castillo, J. (2017). Chitosan mixed with beneficial fungal conidia or fungicide for bean (phaseolus vulgaris 1.) seed coating. Interciencia Rev. Cienc. y Tecnol. América 42, 307-312.

Sakamoto, C. K., \& Silveira, I. O. (2019). Como fazer projetos de Iniciação Científica. Pia Sociedade de São Paulo-Editora Paulus.

Shan, D., Han, E., Xue, H., and Cosnier, S. (2007). Self-assembled films of hemoglobin/laponite/chitosan: Application for the direct electrochemistry and catalysis to hydrogen peroxide. Biomacromolecules 8, 3041-3046.

Shan, D., Li, Q. B., Ding, S. N., Xu, J. Q., Cosnier, S., and Xue, H. G. (2010). Reagentless biosensor for hydrogen peroxide based on self-assembled films of horseradish peroxidase/laponite/chitosan and the primary investigation on the inhibitory effect by sulfide. Biosens. Bioelectron. 26, 536-541.

Sheikhi, A., Afewerki, S., Oklu, R., Gaharwar, A. K., and Khademhosseini, A. (2018). Effect of ionic strength on shear-thinning nanoclay-polymer composite hydrogels. Biomater. Sci. 6, 2073-2083.

Sundhoro, M., Park, J., Jayawardana, K. W., Chen, X., Jayawardena, H. S. N., and Yan, M. (2017). Poly(HEMA-co-HEMA-PFPA): Synthesis and preparation of stable micelles encapsulating imaging nanoparticles. J. Colloid Interface Sci. 500, 1-8.

Wiatrak, P. (2013). Infuence of seed coating with micronutrients on growth and yield of winter wheat in Southeastern Coastal Plains. Am. J. Agric. Biol. Sci. $8,230-238$.

Hernandez, A. V., Marti, K. M., \& Roman, Y. M. (2020). Meta-Analysis. Chest, 158, s97-s102.

Wu, Z., Huang, X., Li, Y. C., Xiao, H., and Wang, X. (2018). Novel chitosan films with laponite immobilized Ag nanoparticles for active food packaging. Carbohydr. Polym. 199, 210-218.

Xu, G., Zhu, Y., Wang, X., Wang, S., Cheng, T., Ping, R., et al. (2019). Novel chitosan and Laponite based nanocomposite for fast removal of Cd(II), methylene blue and Congo red from aqueous solution. E-Polymers 19, 244-256.

Zanini, V. P., López De Mishima, B., and Solís, V. (2011). An amperometric biosensor based on lactate oxidase immobilized in laponite-chitosan hydrogel on a glassy carbon electrode. Application to the analysis of 1-lactate in food samples. Sensors Actuators, B Chem. 155, 75-80.

Zhang, X., Fan, J., Lee, C. S., Kim, S., Chen, C., and Lee, M. (2020). Supramolecular Hydrogels Based on Nanoclay and Guanidine-Rich Chitosan: Injectable and Moldable Osteoinductive Carriers. ACS Appl. Mater. Interfaces 12, 16088-16096. 
Research, Society and Development, v. 10, n. 13, e132101320903, 2021

(CC BY 4.0) | ISSN 2525-3409 | DOI: http://dx.doi.org/10.33448/rsd-v10i13.20903

Ziani, K., Ursúa, B., and Maté, J. I. (2010). Application of bioactive coatings based on chitosan for artichoke seed protection. Crop Prot. $29,853-859$. 